\title{
Forms of public participation in the sustainable development of the city (on the example of the city of Yekaterinburg, Russia)
}

\author{
Nadezhda Sivkova, and Anastasia Novgorodtseva \\ Ural Federal University named after the first President of Russia B.N. Yeltsin, st. Mira, 19, 620002 \\ Yekaterinburg, Russia
}

\begin{abstract}
The city space is permeated with structural and functional opportunities for public participation in solving its problems. This is due to both the existence of a regulatory framework and the willingness and intention of citizens to express their opinion through indirect and direct forms of participation. Direct forms of participation, such as voting and referendums, rallies and pickets, arouse greater interest of city residents by their timeliness, adequacy in the presence of well-built communication channels of local government bodies and the population. The results of the survey and expert interviews about the presence of an active public and community in the city of Yekaterinburg indicate both successful stories of interaction and demonstrate the possibilities for growth and improvement of this process. One of such forms of development can be the transfer of communication to the Internet space of the official websites of local governments and social networks.
\end{abstract}

\section{Introduction}

The development of the city is inextricably linked with the analysis of the activity of the local community, with the analysis of those forms of participation of the population in management processes that are available, possible and created within the framework of local self-government (in the world experience there are different practices due to the current laws of the country). It is obvious that in modern reality, thanks to the processes of globalization, the development of the Internet, residents of individual cities can get acquainted with various world practices of public participation in solving specific problems of the city, this gives rise to an interest in expanding forms of participation, erasing national borders.

The local community is interested in living comfortably in a particular area, taking into account its history, infrastructure, and geography. It is the townspeople who, in their daily practices, face pressing problems, can become a source of information, as well as experts due to their professional interests in solving specific problems of the city (for example, ecology, construction) [1,2].

In Russia, thanks to the legislative framework (Federal Law No. 131 "On General Principles of Organization of Local Self-Government in the Russian Federation" dated October 6, 2003 [3]), the following forms of public participation are in force: direct 
participation through referendums, conferences, gatherings, participation in public hearings , participation in public opinion polls; and mediated - by choosing their representatives deputies [4]. Within the framework of this article, the emphasis will be placed on the readiness of citizens to take a direct part in solving the problems of city development (for example, the city of Yekaterinburg).

The city of Yekaterinburg was not chosen by chance. It was in it in 2013 that Roizman E.V., a candidate not supported by the authorities, won the election of the mayor of the city. The main source of his election campaign was meetings with voters and organizing supporters through the Internet [4]. In 2019, in Yekaterinburg, the townspeople went to a peaceful protest to preserve the territory of the park for the townspeople as a recreation and leisure area, opposed the construction of the temple. It is obvious that an active community has formed in this city, ready to fight and defend their rights and maintain comfortable living conditions. At the same time, the city has a strategic program "Yekaterinburg - a city of active citizens and social harmony" within the framework of the strategic plan for the development of Yekaterinburg in the direction of "development of civil society and local government" [5], the purpose of which is: the formation of an active urban community, and the development of feedback local government bodies.

\section{Materials and Methods}

Indirect public participation in solving city problems is closely related to the issues of the effectiveness of the elected deputies of local self-government in solving the problems of the tax base and city debts, improving the quality of health care and education [6]. And the direct participation of citizens can be expressed in taking into account their opinion when changing the boundaries of growing cities through polls or referendums, voting $[7,8]$.

Key issues raised by researchers with regard to public participation in solving problems are issues of trust / distrust of local authorities, issues of activity / passivity of citizens due to a feeling of powerlessness, lack of faith in the effectiveness of attempts to solve specific problems $[4,9,10]$.

To understand the possibility and importance for the citizens of a particular city to participate in solving urban issues, a study was conducted that combines both quantitative and qualitative collection of primary data. As part of the quantitative strategy, a survey of residents of the city of Yekaterinburg $(\mathrm{N}=400)$ was carried out on the prospects for participation of the city's public in the activities of local self-government bodies. As part of a quality strategy, a series of semi-formalized interviews with experts from the media, science and government were carried out. It also collected secondary information statistics, interviews and media articles, regulations from open sources. Methods of system analysis, structural and functional approach were used to analyze information [11].

\section{Results and Discussion}

The willingness of the population of Yekaterinburg to take part in the discussion of the city's problems is quite high - $81 \%$ (where 32\% - expressed their readiness in general and $49 \%$ - expressed their readiness in some issues). At the same time, only $13 \%$ are not ready to take part.

To successfully solve the problems of the city, the townspeople consider it necessary, first of all, to practice aimed at improving the work of local self-government bodies, and, secondly, to involve the public in solving the problems of the city (Table 1). So, firstly, interaction at the level of authorities - to actively fight against corruption of officials $(53 \%)$, to make the budget of the city and its districts transparent for the population (48\%), to 
present a clear program for the development of the city, to introduce a report of deputies on implemented projects, create conditions for the efficient operation of production, education and medicine in the city. Secondly, to involve citizens in the search for solutions to the city's problems (35\%), to develop public activity $(27 \%)$.

Experts say about the introduction of reports and the involvement of the public in solving problems, emphasizing that this is an institutional issue, since it is required to understand under what conditions and how to inform citizens, and how and in what time frame to implement public protections. "You need to understand that we will never be able to satisfy the desires of everyone. Therefore, this should be clearly understood by all parties who want to be participants in certain processes there. It is important to be able to build this opportunity with public experts, councils, associations and businesses. But it must be integrated into the general system of work of the city administration and the city Duma in such a way that it is carried out in a timely manner. In order for people to understand how the park next to their house will look like, people need to be informed about this, and if we want them to make some kind of knowledge cut or protection of a project, then the administration must also prepare it in such a way as to be in time all this must be done before the budget process and before the approval of how it will begin to be implemented in spring "(expert, government, man).

"You have to go out to people and explain. Come out and explain. There is a big problem related to the fact that we do not have a normal channel for communication between the authorities and the people. The local press could act as such a channel, now there is no local press, there is, but no one reads it. Social networks - but, unfortunately, no one to use from that side is still of high quality. We need to create channels for direct communication "(expert, media, man).

Shitova E.A. emphasizes the importance of the main goal of communication with the population - the creation of trusting relationships, this can be achieved through the creation of "information openness of power" through Internet technologies [12]. The emphasis can be shifted both to the official websites of LSG bodies, and to publications in local media.

Table 1. Opinion of the townspeople on the ways and practices of increasing the efficiency of solving the problems of the city of Yekaterinburg

\begin{tabular}{|c|c|}
\hline Ways to improve efficiency & $\% *$ \\
\hline To actively fight against corruption of officials & $52 \%$ \\
medicine, etc. in the town & $48 \%$ \\
\hline Create conditions for the efficient operation of production, education, & $45 \%$ \\
\hline Make the budget of the city and its districts transparent for the population & $44 \%$ \\
\hline Develop a clear and understandable city development program & $43 \%$ \\
\hline Introduce a report of the deputies on what they have done to solve the city's & $39 \%$ \\
\hline Return the election of the Head of the city by the population of Yekaterinburg & $36 \%$ \\
\hline Increase the professionalism of officials of the Administration and city districts & $35 \%$ \\
\hline To involve citizens in the search for solutions to the city's problems & $32 \%$ \\
\hline Involve science, experts in solving city problems & $27 \%$ \\
\hline Develop public activity of citizens & $23 \%$ \\
\hline Actively introduce new management methods at the city and district level & $18 \%$ \\
\hline
\end{tabular}

* The amount exceeds $100 \%$, since each respondent could give more than 1 answer

Age differences among city dwellers are important, as older people are more interested in increasing the transparency and professionalism of officials, that is, they assume that it is 
enough to strengthen control over professionals to solve the problems of the city (to increase the professionalism of officials of the Administration and city districts - $53 \%$, to actively fight corruption officials - 65\%). At the same time, the lowest percentage of willingness to come up with initiatives on the part of the townspeople is among the elderly only $18 \%$. Middle-aged persons are more interested than other age groups in obtaining information - to make the budget of the city and its districts transparent and accessible to the public, to introduce a report of deputies on what they have done to solve the city's problems. Middle-aged citizens and young people are ready to involve citizens in looking for solutions to city problems (38\% in each group). But it is young people who are ready for broad participation: to develop public activity of citizens (35\%), to involve science and experts in solving the city's problems (37\%). In terms of gender differences, it is obvious that men are more confident than women in the effectiveness of attracting experts in solving city problems ( $46 \%$ versus $24 \%$ ).

Table 2. Willingness of citizens to take part in various forms of solving local problems

\begin{tabular}{|c|c|}
\hline Forms of solving local problems & $\% *$ \\
\hline Poll (referendum) - voting on options for solving urban problems & $60 \%$ \\
\hline Development of city development projects with public participation & $38 \%$ \\
\hline Public hearings - discussion of city government projects & $31 \%$ \\
\hline Meetings of citizens to discuss options for solving city problems & $27 \%$ \\
\hline Submission of proposals for solving problems of a city or district & $23 \%$ \\
\hline Submission of complaints to the City Administration & $21 \%$ \\
\hline Addressing complaints and suggestions to the deputies of your district & $18 \%$ \\
\hline Rallies, pickets & $15 \%$ \\
\hline Gathering of citizens & $14 \%$ \\
\hline Lawmaking initiative of organized population groups & $13 \%$ \\
\hline
\end{tabular}

* The amount exceeds $100 \%$, since each respondent could give more than 1 answer

Let us consider those forms of participation that citizens consider the most effective and in which they are really ready to take part (Table 2). Obviously, the majority is ready to participate in polls, referenda $(60 \%)$, this form allows you to attract attention and get feedback from a large number of citizens. Also, the local community is interested in taking part in the development of projects for the development of the city $(38 \%)$, this rather involves the participation of the most active and interested citizens. It is important that the least preferred forms of participation are rallies, pickets, gatherings of citizens and the lawmaking initiative of organized groups of the population.

Experts emphasize that the townspeople are actively showing dissatisfaction and are ready to communicate with the authorities, when it comes to the territory of their everyday life, to the way of life, then the issue of developing projects with public participation becomes the most important aspect. "An example is the Leninsky District: there is such a center" Druzhba ", children go there, adults from all over the Leninsky District go there, and there should be a landscaped area next to it. And the outraged residents, although Vysokinsky comes to them, the reception administration visits them, they start saying "No, we don't need a playground, we want squirrels to be preserved here, trees to be preserved," and so on. They meet with these people, discuss with them, the trees are not damaged, the improvement is going on as it should. What we have - we have landscaping, playgrounds, preserved squirrels"(expert, authority, man).

Some preferences of age groups are interesting, as the older generation is more inclined to participate in meetings of citizens and public hearings, at the same time filing complaints to the city administration, filing complaints and proposals to the deputies of their district is 
no less enthusiastic. Middle-aged representatives, unlike other age groups, are characterized by a greater interest in lawmaking. And among young people there are more of those who are ready to go to rallies and pickets. And it is among young people that most of all those who consider it important to develop city development projects with public participation $(52 \%)$. From the point of view of gender differences, one can emphasize the regularity that among men there are twice as many of those who are ready to go to rallies and pickets than among women.

Zaborova E.N. emphasizes that the rise of citizens to rallies and pickets can occur spontaneously in a situation of high awareness (factor of activation) and growth of education of the population (factor of directed activity), or it can be the result of purposeful influence [4]. Thus, the most vulnerable groups are youth and men.

\section{Conclusion}

It is obvious that the willingness of citizens to participate in solving city problems is situational. "The sphere where social tension is created is the sphere of public interest. Accordingly, as soon as the tension there subsides, the interest disappears "(expert, science, man). In general, city dwellers tend to take part in public opinion polls as a form not only of assessing and agreeing with development programs, but also as an opportunity to speak out and identify problems that concern them. Preference is given to passive forms of participation - voting, hearings, inactive - rallies, pickets.

To increase civic engagement, it is important to form communication channels, and in modern reality it is an Internet space through the official websites of local governments, NGOs, and through social networks.

\section{Acknowledgements}

We would like to express our gratitude to the students of the Department of Political Science and Sociology with whose active participation this study took place - Elvina Bakhtigareeva, Yegor Veprev, Artemy Grigoryan, Nikita Danilov.

\section{References}

1. Y. Fu, W. Ma, Sustainable urban community development: A case study from the perspective of self-governance and public participation, Sustainability (2020)

2. M. Kozová, Z. Dobšinská, E. Pauditšová, I. Tomčíková, I. Rakytová, Forest Policy and Economics, 89, 31 (2018)

3. Consultant Plus, http://www.consultant.ru/

4. E.N. Zaborova, Management issues, 42 (2014)

5. Official portal Yekaterinburg, https://yekaterinburg.rf/

6. Vzglyad Delovaya Gazeta, https://vz.ru/

7. Reforming the system of organization of LSG in large cities and urban agglomerations: possible approaches, Analytic note (2013)

8. Z. Ivanova, N. Danilina, Public hearing procedure in the management of city development: Analysis of the world experience, MATEC Web of Conferences, 251 (2018)

9. O.V. Ustinova, Yu.P. Savitskaya, Historical and social educational thought, 257 (2014)

10. E.V. Frolova, Sociological studies, 59 (2016) 
11. G.O. Barbakov, I.A. Kurashenko, O.V. Ustinova, Fundamental research, 746 (2015)

12. E.A. Shitova, Mediasphere, 118 (2019) 